\section{First Flights by Petrel}

Petrel, Britain's small research rocket, has recently made successful test flights from a range at South Uist in the Hebrides. Petrel is a spin-stabilized rocket, nine feet long, capable of carrying a $30 \mathrm{lb}$. payload to a height of 81 miles, and is being developed at the request of the Science Research Council for use by universities and other organizations.

In flight, Petrel is stabilized by six fins, set to give a spin rate of about ten revolutions per second at burnout. Propulsion is provided by an end-burning plastic propellant motor called Lapwing, which burns for 32 seconds. A boost at take-off is provided by three small motors mounted in a special boost carriage which separates from the rocket shortly after leaving the launcher and, after a parachute descent, can be used again. With relentless consistency, these motors are called Chick. Petrel is fired from a mobile launcher which consists of a 21 inch diameter tube, 32 feet long, mounted on a 3-ton truck chassis. At the lower end of the launcher tube there is a fibreglass section which enables the rocket telemetry to be operated while the rocket is in the tube. It is also possible to conserve electrical power by using an external supply while the rocket is in the launcher, and disconnecting automatically a few seconds before launching.

The rocket has a standard forebody assembly which suits most experiments, but special heads can be designed if necessary. The development programme for Petrel has been paid for by the Science Research Council and carried out by Bristol Aerojet, Ltd., the Rocket Propulsion Establishment at Westcott and the Atomic Energy Authority. The SRC expects that the first experiment to be flown will be designed by a team from the University of Glasgow.

\section{Parliament in Britain}

Select Committee

THE Select Committee on Science and Technology held a meeting in camera on June 8, at which it may be assumed that it discussed progress in its investigation of the British nuclear reactor programme. The committee hopes to finish proceedings in July of this year and to publish its findings in September.

\section{Overseas Students}

Mr A. Crosland, Secretary of State for Education and Science, announced that Mr T. A. F. Noble, ViceChancellor of the University of Leicester, had agreed to serve as chairman of the advisory board which was being set up in connexion with the Overseas Students' Special Fund. Mr R. Twite would act as secretary, and Mr G. Martin, President of the National Union of Students, and Mr G. Foulkes, President of the Scottish Union of Students, were being invited to act as assessors. Mr N. Doodson, Mr Lyndon H. Jones, Lady Llewelyn Davies, Very Rev R. L. Small, Mr R. J. Stewart and Mr J. H. Taylor had also agreed to serve on the board, which will give advice on the spending of the fund set up to minimize hardship to overseas students. (Written answer, June 5.)

\section{Marine Science}

MR G. RoBerts, Minister of State, Department of Education and Science, gave the following list of marine laboratories financed by grants from the Natural
Environment Research Council: National Institute of Oceanography, $£ 741,000$; Marine Biological Association, Plymouth, $£ 234,000$; Scottish Marine Biological Association, (a) Millport, $f 107,000$; (b) Oban (new laboratory), £161,000; (c) Edinburgh, $£ 125,000$; Port Erin, $£ 36,000$; Fisheries Biological Unit (at Aberdeen University), $£ 42,000$; Dove Marine Laboratory, Newcastle University, $£ 32,000$; Marine Invertebrate Bio$\operatorname{logy}$ Unit at Bangor University, $£ 11,000$; and the Fisheries Helminthology Unit, $£ 12,000$. The Ministry of Agriculture, Fisheries and Food contributes $£ 1,190,000$ to the Marine Research Laboratory, Lowestoft, $£ 78,000$ to the Shellfish Laboratory, Burnham-onCrouch, and $£ 42,000$ to the Fisheries Experiment Station, Conway, and the Department of Agriculture and Fisheries for Scotland, $£ 642,000$ to the Marine Laboratory, Aberdeen. (Written answer, June 7.)

\section{Desalination}

Mr A. Wedgwood Benn, Minister of Technology, said that Weir Westgarth, Ltd., had recently succeeded with a tender for a large distillation plant of advanced design in Qatar. Developments in electrodialysis to make it the most economical process for desalting brackish water were now being tested in a pilot plant and Britain could offer these plants with a guaranteed performance up to 6 million gallons per day (US). The Atomic Energy Authority and industry were also working on the freeze process and package plants and shipborne desalination plants to cater especially for the needs of island communities were also being studied. In addition to the sea-water test facility at Troon, Ayrshire, a 50,000 gallon a day plant had been built in association with William Boby in Essex. (Answer, June 6.)

\section{Preservation for Science}

THE Areas of Special Scientific Interest Bill which Mr M. Kimball introduced into the House of Commons on June $\mathbf{5}$ is intended to give powers of protection so that greater use can be made of the areas of interest once they have been designated. Mr Kimball said that there were about 2,080 such sites in the British Isles and that the Bill had the whole-hearted support of the County Naturalists Trusts. (Bill introduced June 5.)

\section{University Charters}

MR G. Roberts, Minister of State, Department of Education and Science, talked of the arrangements for granting university charters, particularly as they affect students. He was answering criticisms in an adjournment debate. While it was open to those drafting a charter to suggest the inclusion of any provisionconsultation with students on discipline, for instancethe suggested provision might be tempered by Privy Council policy or because of the need to meet representations made by a third party. Mr Roberts said that the Privy Council had already suggested that the senate and council of the new universities should establish joint committees of themselves and representatives of the student body and provide a procedure by which a student who was suspended or expelled had a right to be formally heard by the senate or a body appointed by the senate before the decision became final. A third provision suggested was for the establishment of an association representing the student body, and the charters and statutes of all the new technological universities incorporated provisions on these lines. (Debate, June 5.) 